\title{
ANALISIS DESAIN PENAMPUNG BAHAN BAKAR BEKAS REAKTOR DAYA EKSPERIMENTAL (RDE) MENGGUNAKAN MCNPX 2.6.0
}

\author{
Guspita Karleni $^{1}$, Muhammad Subekti ${ }^{2}$ \\ ${ }^{1}$ Jurusan Fisika, Universitas Sriwijaya, \\ ${ }^{2}$ Pusat Teknologi dan Keselamatan Reaktor Nuklir - BATAN \\ Email: guspita0608@gmail.com
}

\begin{abstract}
ABSTRAK
ANALISIS DESAIN PENAMPUNG BAHAN BAKAR BEKAS REAKTOR DAYA EKSPERIMENTAL (RDE) MENGGUNAKAN MCNPX 2.6.0. Pembangunan fasilitas penyimpanan bahan bakar bekas merupakan suatu kebutuhan yang sangat penting. Dosis radiasi yang dihasilkan oleh bahan bakar bekas tersebut masih sangat besar sehingga dibutuhkan fasilitas untuk penyimpanan bahan bakar bekas dalam jangka panjang. Aspek keselamatan yang berkaitan dengan pembangunan fasilitas penyimpanan bahan bakar bekas cukup banyak, namun aspek pertama yang perlu diperhatikan adalah untuk menghindari kekritisan. Untuk menyelesaikan analisis desain media penampung bahan bakar bekas, program MCNPX.2.6.0 dapat digunakan. Dari hasil simulasi dan analisis data, diperoleh nilai tebal perisai yang aman untuk menahan paparan radiasi yaitu minimum $21,9 \mathrm{~cm}$ untuk arah radial, minimum $19 \mathrm{~cm}$ untuk bagian bawah arah radial, dan minimum $37 \mathrm{~cm}$ untuk bagian atas arah radial. Di samping data tebal perisai, pada simulasi ini juga diperoleh distribusi laju dosis pada berbagai permukaan perisai untuk tebal perisai radiasi $21,9 \mathrm{~cm}$, yaitu nilai laju dosis pada permukaan perisai bagian atas adalah sebesar 9.2376E-08 Sv/jam, dan pada permukaan perisai bagian bawah dengan tebal $19 \mathrm{~cm}$ sebesar 5.1549E-07 Sv/jam.
\end{abstract}

Kata kunci: penampung bahan bakar bekas, RDE, MCNPX.2.6.0, perisai radiasi

\section{ABSTRACT}

ANALYIS OF SPENT FUEL STORAGE DESIGN FOR EXPERIMENTAL POWER REACTOR (EPR) USING MCNPX 2.6.0. The construction of spent fuel storage facility is a very important requirement. The radiation exposure generated from the spent fuel inside is still significant so that a storage facility is required for a long term duration. There are many safety aspects related to the spent fuel storage facility, but the first one to be considered is to avoid criticality. To accomplish the design analysis of spent fuel storage, MCNPX 2.6.0 program can be used. From the simulation results and data analysis, thickness values of the shield, which is safe to withstand radiation exposure are obtained, which are at least $21.9 \mathrm{~cm}$ for radial direction, $19 \mathrm{~cm}$ for a radial bottom, and $37 \mathrm{~cm}$ for a radial top. In addition to the shield's thickness, this simulation also obtains the distribution of dose rate at the top surface of the shield for the $21.9 \mathrm{~cm}$ thickness, which is $9.2376 E-08 \mathrm{~Sv} / \mathrm{hour}$, and at the surface of the bottom shield with $19 \mathrm{~cm}$ thickness of 5.1549E-07 Sv/hour.

Keywords: spent fuel storage, EPR, MCNPX.2.6.0, radiation shield 


\section{PENDAHULUAN}

RDE atau reaktor daya eksperimental merupakan reaktor nuklir yang dapat digunakan untuk pembangkit listrik, pembangkit panas dan untuk memproduksi hidrogen. Karena sifatnya yang eksperimental maka pengoperasian reaktor nuklir tersebut lebih banyak untuk tujuan percobaan dalam meningkatkan penguasaan teknologi [2]. Pembangunan fasilitas penyimpanan bahan bakar bekas merupakan suatu kebutuhan yang sangat penting, yang mendorong penulis untuk melakukan analisis desain media penampung bahan bakar bekas reaktor daya eksperimental. Mengingat bahwa dosis radiasi yang dihasilkan oleh bahan bakar bekas Reaktor Daya Eksperimental (RDE) tersebut masih sangat besar mengingat fasilitas yang dibutuhkan untuk penyimpanan bahan bakar bekas yang berjangka panjang. Aspek keselamatan yang berkaitan dengan pembangunan fasilitas penyimpanan bahan bakar bekas cukup banyak, namun aspek pertama yang perlu diperhatikan adalah menghindari kekritisan. paparan radiasi tidak boleh melebihi batas yang ditentukan oleh BAPETEN dan pelepasan zat radio aktif harus dihindarkan. Ketentuan untuk limitasi dosis radiasi yang dijelaskan oleh Badan Pengawas Tenaga Nuklir (BAPETEN) Nomor 4 Tahun 2013 untuk pekerja radiasi dengan dosis efektif rata -rata sebesar $20 \mathrm{mSv}$ pertahun. Sehingga tempat media penampung bahan bakar tersebut harus memiliki tingkat keselamatan yang tinggi.

\section{TEORI}

\section{Deskripsi Teras HTR}

Teras HTR pebbel bed pada umumnya berisi ratusan ribu bola bahan bakar dimana porositas di antara celah-celahnya dialiri pendingin gas helium. Volume helium dari total volume teras reaktor diperkirakan sekitar $6 \%$. Setiap pebble yang berdiameter $6 \mathrm{~cm}$ terdiri atas 5.000 hingga 20.000 partikel bahan bakar berlapis TRISO [5].

Tabel 1. Spesifikasi Bola Bahan Bakar HTR Pebble Bed dan Partikel Berlapis TRISO [1]

\begin{tabular}{ll}
\hline Fuel Pebble & $1.73 \mathrm{~g} / \mathrm{cm}^{3}$ \\
Density of graphite in matrix and outer shell & $5.0 \mathrm{~g}$ \\
Heavy metal (uranium) loading (weight) per pebble & $17 \%$ \\
Uranium enrichment ( ${ }^{235} \mathrm{U} /$ total U by weight) & $4 \mathrm{ppm}$ \\
Equivalent natural boron content of impurities in uranium & $1.3 \mathrm{ppm}$ \\
Equivalent natural boron content of impurities in graphite & 0.61 \\
Volume fraction of pebbles in the core & 10.4 \\
$\mathrm{UO}_{2}$ density $\left(\mathrm{g} / \mathrm{cm}^{3}\right.$ ) & $\mathrm{Buffer} / \mathrm{PyC} / \mathrm{SiC} / \mathrm{PyC}$ \\
$\mathrm{Coating}^{3}$ layer materials (starting from kernel) & $1.1 / 1.9 / 3.18 / 1.9$ \\
$\mathrm{Coating}$ layer density (g/cm ${ }^{3}$ ), respectively & 8335 \\
Average number of fuel particles per pebble & $5.0248 \%$ \\
Volume fraction of fuel particles in pebble fuel zone ${ }^{(\mathrm{a})}$ & \\
\hline Dummy Pebble & $1.84 \mathrm{~g} / \mathrm{cm}^{3(\mathrm{~b})}$ \\
\hline Density of graphite in dummy pebbles & $0.125 \mathrm{ppm}^{(\mathrm{b})}$ \\
\hline Equivalent natural boron content of impurities in graphite in dummy pebbles
\end{tabular}


Komposisi dan diameter kernel bahan bakar dipertimbangkan dan diseleksi menurut desain dan kapabilitas sebuah HTR pebble bed yang spesifik. HTR pebble bed dapat menggunakan kernel dari material bahan bakar yang berbeda dalam desain reaktor yang sama, meskipun mungkin tidak pada waktu yang sama. Beberapa jenis HTR pebble bed dapat memanfaatkan thorium, plutonium dan uranium alam, serta uranium yang diperkaya. Proyek untuk mengembangkan pebble dan reaktor yang mengadopsi bahan bakar MOX (mixed-oxide) juga sedang berlangsung di beberapa institusi riset nuklir di dunia. Bahan bakar MOX merupakan campuran uranium dan plutonium yang berasal dari bahan bakar bekas reaktor air tekan PWR (pressurized water reactor) atau reaktor air didih BWR (boiling water reactor) yang diolah-ulang atau bahan bakar hulu ledak nuklir yang didekomisioning [4].

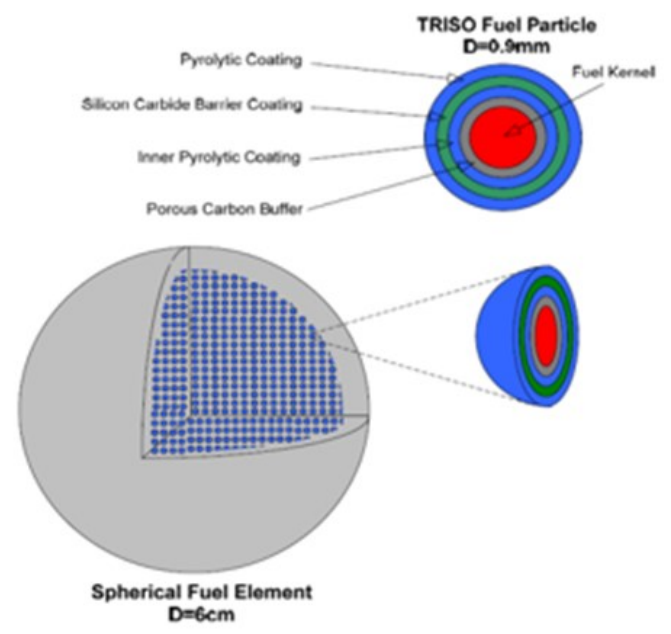

Gambar 1. Skema Geometrik Bola Bahan Bakar HTR Pebble-Bed [5].

\section{Proteksi Radiasi}

Radiasi gamma merupakan salah satu jenis radiasi elektromagnetik dengan frekuensi paling tinggi diantara jenis gelombang elektromagnetik lainnya. Karena tidak bermuatan listrik, maka radiasi ini mempunyai daya tembus yang sangat tinggi bergantung pada ener ginya. Apabila radiasi elektromagnetik menerobos bahan perisai, maka sebagian dari radiasi tersebut akan terserap oleh bahan. Sebagai akibatnya, intensitas radiasi setelah melalui bahan perisai menjadi lebih kecil dibandingkan intensitas semula. Dalam peristiwa interaksi ini tidak terjadi penyerapan energi radiasi, melainkan terjadi penyerapan sebagian intensitas radiasi saja [6]. Intensitas radisi gamma dapat berkurang melalui tiga macam peristiwa interaksi antara radiasi dengan materi, yaitu: efek fotolistrik, hamburan Compton dan produksi pasangan. Dalam proteksi radiasi, peristiwa ini biasanya dimanfaatkan untuk menurunkan intensitas radiasi menggunakan bahan perisai. Karena terjadi penyerapan sebagian intensitas radiasi, maka intensitas radiasi yang keluar dari bahan perisai menjadi lebih rendah dibandingkan intensitas mula-mula. Tebal bahan perisai sangat berpengaruh terhadap tingkat pengurangan intensitas. Semakin tebal perisai akan semakin kecil radiasi yang lolos dari perisai tersebut [6].

\section{Aspek Kekritikalitas dan Aspek Radiologi}

Nilai faktor multiplikasi (k) yang berkaitan dengan kekritisan reactor dipengaruhi oleh berbagai parameter, di mana parameter-parameter ini dipengaruhi oleh temperatur. Dengan demikian, perubahan temperatur reaktor akan mengakibatkan perubahan pada nilai $\mathrm{k}$, sehingga mempengaruhi pula nilai reaktivitas keseluruhan sistem. Efek yang demikian memiliki pengaruh yang besar pada keselamatan operasi reaktor Sebelum dipindahkan ke ISFSF. keutuhan bahan bakar bekas harus diperiksa terlebih dahulu Bahan bakar cacat ditempatkan dalam wadah khusus untuk menghindari kontaminasi dan ada kemungkinan terjadi kerusakan bahan bakar selama pemindahan dan penempatannya di dalam penyimpanan. Sebab-sebab munculnya gas hasil fisi dari bahan bakar bekas karena retak 
nya kelongsong yang hal ini dapal ditimbulkan karena:

- Bahan bakar jatuh.

- Bahan bakar terkena korosi.

Untuk menganalisis pelepasan zat radioaktif tersebut ke lingkungan diasumsikan bahwa gas fisi keluar dari kelongsong tersebut.

\section{Jaminan Keselamatan}

Jaminan keselamatan suatu fasilitas merupakan hal yang sangat penting. Sebagai dasar acuan untuk keselamatan yang berkaitan dengan fasilitas penyimpanan dan penanganan bahan bakar bekas diacu dari IAEA Safety Guide No. 50-8G-DIO dan ICRP 60 tahun 1990. Prinsip keselamatan tersebut adalah: Mencegah terjadinya kritikalitas, paparan radiasi yang melebihi batas dan pelepasan zat radioaktif [7]. Objektif paling penting dalam desain tersebut adalah untuk melindungi orang-orang dan lingkungan akan efek membahayakan dari radiasi. Pemenuhan objektif keselamatan fundamendal ini difasilitasi dengan 3 pengukuran berikut: a. Untuk mengendalikan paparan radiasi pada orang-orang dan pelepasan material radioaktif ke lingkungan; b. untuk membatasi kemungkinan kejadian yang dapat mengarah pada kehilangan kendali akan teras reaktor nuklir, reaksi berantai, sumber radioaktif, atau sumber radiasi lain; c. untuk memitigasi konsekuensi dari kejadian tersebut jika benar benar terjadi [7].

\section{Badan Pengawas Tenaga Nuklir (BAPETEN)}

BAPETEN (Badan Pengawas Tenaga Nuklir) merupakan lembaga yang mengeluarkan peraturan dan standar teknis untuk desain reaktor tentang Keselamatan Radiasi Pengion dan Keamanan Sumber Radioaktif. BAPETEN mengeluarkan peraturan limitasi dosis, dimana limitasi dosis tersebut berlaku untuk:

- $\quad$ Pekerja radiasi

- pekerja magang untuk pelatihan kerja, pelajar, atau mahasiswa yang berumur 16 tahun sampai dengan 18 tahun

- $\quad$ anggota masyarakat

Dosis Efektif rata-rata untuk pekerja radiasi sebesar $20 \mathrm{mSv}$ (duapuluh milisievert) per tahun dalam periode 5 (lima) tahun, sehingga Dosis yang terakumulasi dalam 5 (lima) tahun tidak boleh melebihi $100 \mathrm{mSv}$ (seratus millisievert). Nilai Batas Dosis Efektif pekerja magang untuk pelatihan kerja, pelajar, atau mahasiswa yang berumur 16 (enambelas) tahun sampai dengan 18 (delapanbelas) tahun memiliki sebesar $6 \mathrm{mSv}$ (enam milisievert) per tahun. Nilai Batas Dosis untuk anggota masyarakat sebesar $1 \mathrm{mSv}$ (satu milisievert) per tahun [8].

\section{MCNPX 2.6}

Metode Monte Carlo merupakan metode yang menggunakan random sampling dari distribusi probabilitas yang diketahui untuk menyelesaikan permasalahan dalam fisika atau matematika. Metode Monte Carlo mensimulasikan partikel individu dan merekam beberapa aspek (penghitungan) perilaku ratarata dari partikel. Monte carlo menyelesaikan permasalahan transport dengan mensimulasikan jejak partikel. Monte Carlo dapat digunakan untuk menduplikasi secara teoritis proses statistik (seperti interaksi partikel nuklir dengan materi) dan sangat berguna untuk masalah-masalah kompleks yang tidak dapat dimodelkan dengan kode komputer yang menggunakan metode deterministic. MCNPX adalah salah satu aplikasi dari kode transport radiasi Monte Carlo yang dapat melacak hampir semua partikel pada hampir semua energi. Ini merupakan pengembangan dari MCNP untuk semua partikel dan semua [10].

\section{METODOLOGI}

Dalam studi analisis desain media penampung bahan bakar bekas ini alat yang digunakan adalah Perangkat Keras (hardware) berupa personal computer (PC) dan program 
MCNPX.2.6.0. Analisis melalui studi pustaka dari berbagai data yang tersedia, yang membahas mengenai keselamatan reaktor, membahas Perisai Radiasi, Reaktor Daya Eksperimental HTR Pebble bed. Dari studi pustaka dari berbagai data didapatkan berkas input, bahan bakar bekas yang telah didinginkan selama 10 Tahun digunakan sebagai masukan pada saat eksekusi program MCNPX. Model media penampung bahanbakar bekas Reaktor Daya Eksperimental (RDE) didesain seperti tangki penyimpanan bahan bakar bekas yang telah diterapkan pada HTR-10 di Cina.

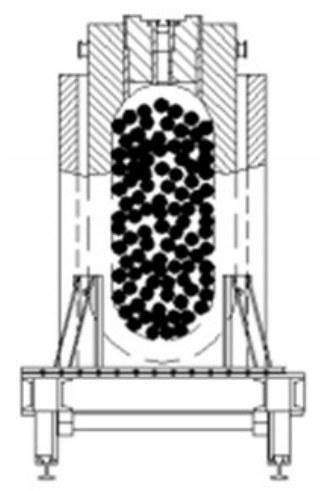

Gambar 2. Desain penampung bahan bakar bekas [3]

Dengan lapisan shielding stainless steel kemudian di isi 2000 bahan bakar bekas berbentuk pebble (bola) dengan bahan graphite. Geometri model media penampung bahan bakar bekas RDE Digambar ditunjukkan pada Gambar 3 .

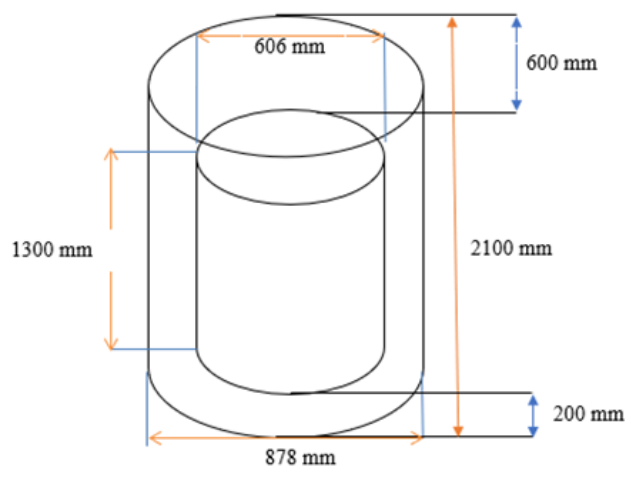

Gambar 3. Geometri dan ukuran penampung bahan bakar bekas

\section{HASIL DAN PEMBAHASAN}

Untuk desain case penampung bahan bakar bekas ini menggunakan bahan stainless steel 304, untuk ketebalan stainless steel ini dapat mempengaruhi nilai intensitas radiasi yang didapat. Dimana intensitas pada beberapa jarak disuatu material dapat dinyatakan dalam bentuk:

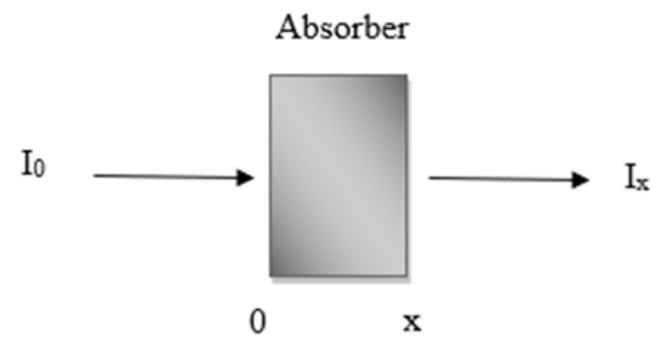

Gambar 4. Proses penyerapan sinar-X

Bergantung oleh:

- Ketebalan penyerap (x)

- $\quad$ Nomor atom penyerap $(\mathrm{Z})$

- Densitas penyerap $(\rho)$

- $\quad$ Energy sinar-X

Persamaan sebagai berikut:

$$
d I(x)=-I(x) \cdot n \cdot \sigma \cdot d x
$$

Dimana dl: perubahan di(dalam) intensitas

- I: intensitas awal

- $\mathrm{n}$ : banyaknya atom $/ \mathrm{cm}^{3}$

- $\mathrm{dx}$ : penurunan ketebalan material

Ketika persamaan ini terintegrasi, menjadi:

$I=I_{0} e^{-n \sigma x}$

Banyaknya atom $/ \mathrm{cm}^{3}$ (n) umumnya dikombinasikan untuk menghasilkan koefisien atenuasi linier. Oleh karena itu persamaannya menjadi:

$$
I=I_{0} e^{-\mu x}
$$

Dimana I: intensitas satuan energy dalam caaya memancarkan kejalur lain beberapa jarak x.

- $\mathrm{I}_{0}$ : intensitas awal satuan energy dalam cahaya

- $\quad \mu$ : koefisien atenuasi linier

- $\quad x$ : jarak 
Model Matematika

$\frac{\Delta I}{I} \propto \Delta x$

$\frac{\Delta I}{I}=-\mu \Delta x$

Dimana $\mu$ : koefisien atenuasi linier

$\frac{d I}{I}=-\mu \Delta x$

$\int_{I_{0}}^{I_{x}} \frac{d I}{I}=-\mu \int_{0}^{x} d x$

$\ln \frac{I_{x}}{I_{0}}=-\mu x$

$\frac{I_{x}}{I_{0}}=\exp (-\mu x)$

$$
I_{x}=I_{0} \exp (-\mu x)
$$
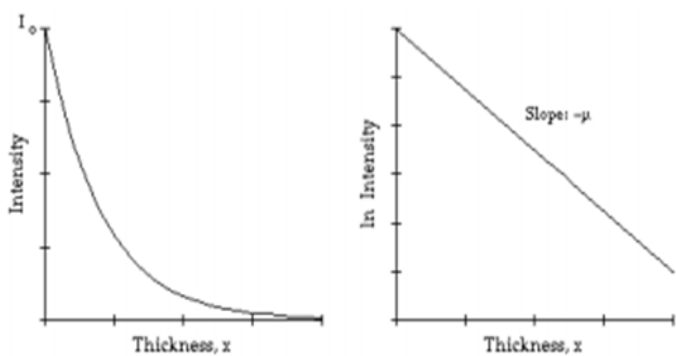

Gambar 5. Hubungan antara ketebalan dengan intensitas
Hasil eksperimen atau simulasi desain yang dibuat menggunakan program MCNP sebagai berikut:

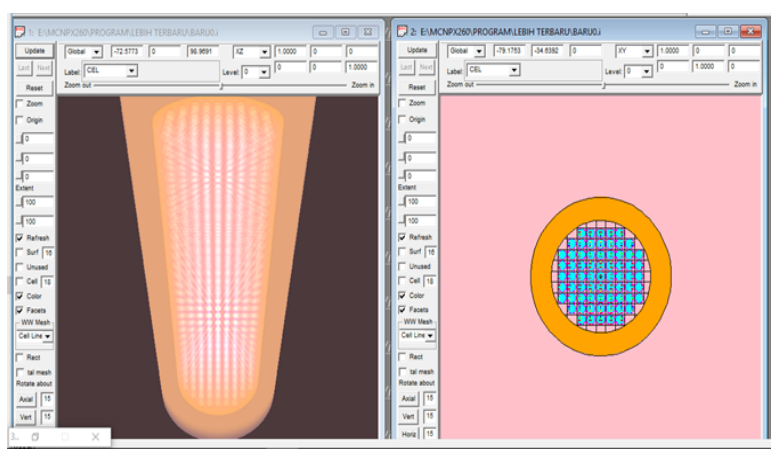

Gambar 6. Desain penampung bahan bakar bekas Transparent 3D

Untuk acuan sebagai dosis radiasi yang diinginkan dilakukan perhitungan sebagai berikut:

- Dosis: $1 \mathrm{mSv} / \mathrm{tahun}$

- 1 tahun $=50$ minggu

- 1 minggu $=5$ hari

- 1 hari $=5$ hari

- 1 tahun $=2000 \mathrm{jam} /$ tahun

- Dosis $=0,0005 \mathrm{mSv} / \mathrm{jam}$

Sehingga untuk nilai dosis radiasi yang aman diserap oleh manusia sebesar 5.0.E-07 Sv/jam. Nilai dosis tersebut yang menjadi perbandingan untuk nilai radiasi yang dihasilkan dari desain penampung bahan bakar bekas tersebut.

Tabel 2 Output dosis radiasi setiap pertambahan diameter ketebalan

\begin{tabular}{|c|c|c|c|c|c|c|c|c|c|c|}
\hline RADIAL & R1 & $\mathrm{R} 2$ & R3 & R4 & R5 & R6 & T1 & $\mathrm{T} 2$ & B1 & B2 \\
\hline DEFAUIT & $1.7794 \mathrm{E}-05$ & $1.0726 \mathrm{E}-05$ & $5.9642 \mathrm{E}-06$ & $2.4471 \mathrm{E}-06$ & $5.0025 \mathrm{E}-07$ & $1.6010 \mathrm{E}-07$ & $1.1523 \mathrm{E}-08$ & $1.7855 \mathrm{E}-08$ & $1.9762 \mathrm{E}-04$ & $2.4016 \mathrm{E}-05$ \\
\hline $1 \mathrm{~cm}$ & $7.1345 \mathrm{E}-06$ & $6.1364 \mathrm{E}-06$ & $3.3763 \mathrm{E}-06$ & $1.4098 \mathrm{E}-06$ & $3.0021 E-07$ & 8.0978E-08 & $3.8854 \mathrm{E}-09$ & $9.2901 \mathrm{E}-09$ & $4.8872 \mathrm{E}-05$ & $8.9738 \mathrm{E}-06$ \\
\hline $2 \mathrm{~cm}$ & $7.9397 \mathrm{E}-06$ & $3.7334 \mathrm{E}-06$ & $2.0190 \mathrm{E}-06$ & $8.3403 E-07$ & $1.7338 \mathrm{E}-07$ & 4.6417E-08 & $1.0004 \mathrm{E}-09$ & $5.4021 \mathrm{E}-09$ & $2.1561 \mathrm{E}-05$ & $3.5020 \mathrm{E}-06$ \\
\hline $3 \mathrm{~cm}$ & $1.0388 \mathrm{E}-05$ & $2.3178 \mathrm{E}-06$ & $1.3121 \mathrm{E}-06$ & $5.3837 \mathrm{E}-07$ & $1.1435 \mathrm{E}-07$ & $3.1765 \mathrm{E}-08$ & $9.3894 \mathrm{E}-10$ & $3.1585 \mathrm{E}-09$ & $5.8768 \mathrm{E}-06$ & $1.2912 \mathrm{E}-06$ \\
\hline $4 \mathrm{~cm}$ & $3.352 \pi \mathrm{E}-06$ & $1.5294 \mathrm{E}-06$ & $9.6118 \mathrm{E}-08$ & $3.3042 E-07$ & $7.0722 \mathrm{E}-08$ & $1.8614 \mathrm{E}-08$ & $3.6493 \mathrm{E}-10$ & $1.8406 \mathrm{E}-09$ & $8.9541 \mathrm{E}-07$ & $5.3061 \mathrm{E}-07$ \\
\hline $5 \mathrm{~cm}$ & $4.3999 \mathrm{E}-07$ & $8.4603 \mathrm{E}-07$ & $4.4686 \mathrm{E}-07$ & $1.8540 \mathrm{E}-07$ & $3.9843 \mathrm{E}-08$ & $1.0412 \mathrm{E}-08$ & $1.3881 \mathrm{E}-10$ & $6.4072 \mathrm{E}-10$ & $5.1549 \mathrm{E}-07$ & $2.459 \mathrm{TE}-07$ \\
\hline $6 \mathrm{~cm}$ & $3.0668 \mathrm{E}-07$ & $4.4941 \mathrm{E}-07$ & $2.6262 \mathrm{E}-07$ & $1.1519 \mathrm{E}-07$ & $2.4968 \mathrm{E}-08$ & $6.7902 \mathrm{E}-09$ & $1.1424 \mathrm{E}-10$ & $3.2774 \mathrm{E}-10$ & $1.1674 \mathrm{E}-07$ & $7.7313 \mathrm{E}-08$ \\
\hline $7 \mathrm{~cm}$ & $1.8263 \mathrm{E}-07$ & $2.1592 \mathrm{E}-07$ & $1.4310 \mathrm{E}-07$ & $6.4692 \mathrm{E}-08$ & $1.4322 \mathrm{E}-08$ & $3.7807 \mathrm{E}-09$ & $7.5300 \mathrm{E}-12$ & $2.7329 \mathrm{E}-10$ & 2. $1140 \mathrm{E}-08$ & $1.6478 \mathrm{E}-08$ \\
\hline $8 \mathrm{~cm}$ & $2.5394 \mathrm{E}-07$ & $1.6268 \mathrm{E}-07$ & $1.1217 \mathrm{E}-07$ & $4.8654 \mathrm{E}-08$ & $9.6246 \mathrm{E}-09$ & $2.5206 \mathrm{E}-09$ & $3.7136 \mathrm{E}-11$ & $1.2018 \mathrm{E}-10$ & $5.8327 \mathrm{E}-09$ & $1.2348 \mathrm{E}-08$ \\
\hline $9 \mathrm{~cm}$ & $9.2376 \mathrm{E}-08$ & $1.0955 \mathrm{E}-07$ & $5.6695 \mathrm{E}-08$ & $2.3737 \mathrm{E}-08$ & $5.3731 E-09$ & $2.0951 \mathrm{E}-09$ & $3.5638 \mathrm{E}-11$ & $7.9852 \mathrm{E}-11$ & $6.9317 \mathrm{E}-09$ & $1.8862 \mathrm{E}-08$ \\
\hline $10 \mathrm{~cm}$ & $6.6631 \mathrm{E}-08$ & $6.7385 \mathrm{E}-08$ & 4.5993E-08 & $2.0713 \mathrm{E}-08$ & $4.7044 \mathrm{E}-10$ & $1.1658 \mathrm{E}-09$ & $4.7427 \mathrm{E}-11$ & $4.2628 \mathrm{E}-11$ & $7.4405 \mathrm{E}-09$ & $1.2707 \mathrm{E}-09$ \\
\hline $15 \mathrm{~cm}$ & $1.6386 \mathrm{E}-09$ & $1.1347 \mathrm{E}-08$ & $6.7751 \mathrm{E}-09$ & $2.6786 \mathrm{E}-09$ & $5.5691 \mathrm{E}-10$ & $1.4435 \mathrm{E}-10$ & $3.9898 \mathrm{E}-15$ & $2.1610 \mathrm{E}-15$ & $5.8905 \mathrm{E}-12$ & 4.071 E -12 \\
\hline
\end{tabular}

Ket: R: right, T: top, B: bottom, warna kuning adalah dosis yang paling aman 


\section{KESIMPULAN}

Program MCNPX dapat digunakan secara baik untuk simulasi desain perisai radiasi. Dari hasil simulasi dan analisis data, diperoleh nilai tebal perisai yang aman untuk menahan paparan radiasi yaitu minimum 21,9 cm untuk arah radial, minimum $19 \mathrm{~cm}$ untuk radial bottom, dan minimum $37 \mathrm{~cm}$ untuk radial top.

\section{UCAPAN TERIMA KASIH}

Penulis mengucapkan terimakasih kepada PTKRN-BATAN yang telah memberikan kesempatan kepada kami untuk melakukan penelitian dan kepada Wahid Luthfi, S.T., dan R. Andhika Putra Dwijayanto, S.T., yang telah mengarahkan dalam proses eksekusiMCNPX.2.6.0.

\section{DAFTAR PUSTAKA}

1. Nuclear Energy Agency. PBMR coupled neutronics / thermal hydraulics transient benchmark - The PBMR-400 Core Design. France, 2006.

2. http://www.batan.go.id/index.php/ id.reaktor-daya-eksperimental-rde. Diakses pada tanggal 10 Juni 2018.

3. Wang J.H., Huang Y.F., Tang Y., Wu B. Natural safety analysis of the spent fuel residual heat removal in loading and storage process of HTR-10. Energy Procedia 2013; 39: 227-239.

4. Zuhair, Suwoto, Adrial H. Studi performa teras inisial HTR pebble bed dengan bahan bakar plutonium oksida. Sigma Epsilon 2017, 21 (1): 2-6.

5. Zuhair, Suwanto, Irianto, I. D. Studi optimasi moderasi neutron dalam teras HTR pebble ped. Laporan Teknis Penelitian 2010, Pusat Teknologi Reaktor dan Keselamatan Nuklir (PTRKN) -BATAN.

6. Yulianti H. dan Akhadi M. Pertumbuhan radiasi di dalam perisai untuk sumber gamma energi tinggi beraktivitas rendah.
Prosiding Seminar Teknologi Keselamatan Radiasi dan Biomedika Nuklir I.

7. Djunaidi dan Prayogo S. Tinjauan pembangunan penyimpanan bahan bakar bekas RSG-GAS dari aspek keselamatan. Prosiding Seminar Teknologi Pendayagunaan Reaktor Riset G.A Siwabessy 1999.

8. Badan Pengawas Tenaga Nuklir (BAPETEN). Proteksi dan Keselamatan Radiasi Dalam Pemanfaatan Tenaga Nuklir. Peraturan Kepala Badan Pengawas Tenaga Nuklir No. 4 Tahun 2013.

9. Rohman B. Koefisien reaktivitas temperatur bahan bakar reaktor Kartini. Jurnal Sains dan Teknologi Nuklir Indonesia 2009; 10 (2): 60-70.

10. Azizah, Abdurrouf, Bunawas. Perkiraan dosis dan distribusi fluks neutron cepat dengan simulasi Monte Carlo MCNPX pada Fantom saat terapi Linac 15 MV. Physis Student Journal - Brawijaya University 2014. 